WOJCIECH ŁĄCZKOWSKI

\title{
TRÓJPODZIAŁ WŁADZ A DOBRO WSPÓLNE
}

I. Trójpodział władz można różnie uzasadniać. Na przykład można odwoływać się do klasyki ustrojowej wywodzacej się od Monteskiusza, który uzasadnił potrzebę podziału władzy publicznej pomiędzy prawodawcę, władzę wykonawczą oraz sądownicza. Ta klasyczna zasada została zaadaptowana w państwach, w których od końca XVIII w. zaczęła odżywać tęsknota nawiązujaca do ateńskiej demos kratos, tj. do władzy ludu. Zdawano sobie jednak sprawę z ograniczonych możliwości sprawowania władzy bezpośrednio przez lud tak, jak na greckiej agorze. Wielkość państw i coraz bardziej złożone problemy społeczno-gospodarcze uniemożliwiają powszechne odwoływanie się do decyzji podejmowanych bezpośrednio przez wszystkich uprawnionych obywateli. Demokracja bezpośrednia musiała więc zostać ograniczona tylko do niewielu najważniejszych spraw, co do których obywatele sa w stanie podejmować świadome i racjonalne decyzje w referendach. W innych sprawach wymagających rozwiązań złożonych, powikłanych problemów lub tysięcy prostszych spraw obywateli lepiej jest, gdy obywatele wybiora przedstawicieli i powierzą im prowadzenie tych spraw lub nawet zaakceptują działalność specjalistów powoływanych w trybie pozawyborczym. Demokracja pośrednia (przedstawicielska) wiąże się najczęściej z wyborem władz prawodawczych na szczeblu centralnym (parlamenty) lub lokalnym (samorządy). Rzadziej wyborom poddawani sa funkcjonariusze władzy wykonawczej (np. prezydenci, burmistrzowie, wójtowie itd.). Pozostali członkowie organów wykonawczych wyłaniani są najczęściej w inny sposób. Na przykład w większym lub mniejszym stopniu zależą od wyników wyborów władzy prawodawczej albo sa efektem odrębnego systemu kładącego nacisk na pozapartyjne (niezależne od preferencji wyborczych) kwalifikacje merytoryczno-zawodowe. Powstaje w ten sposób profesjonalna, apolityczna kadra, tzw. służba cywilna. Wyrazistość podziału pomiędzy obydwoma władzami niekiedy się zaciera, m.in. przez dopuszczenie do zbyt dużych możliwości kształtowania szerokich kadr egzekutywy przez władzę prawodawczą lub nawet - tak jak przewiduje to Konstytucja RP - do łączenia stanowiska ministra z funkcją posła.

Odrębna, trzecią władza, jest władza sądownicza. Powstaje jednak dylemat, w jaki sposób ma ona być powoływana. Na rozwiązanie tego dylematu wpływ ma to, jakimi kompetencjami powinien dysponować sędzia. W prostych, codziennych sprawach sędzią może być, cieszący się zaufaniem, jeden z obywateli wyłoniony w wyborach powszechnych. W ten sposób mogą być tworzone sądy pokoju, sądy rozjemcze bądź powoływani ławnicy w sądach niższych instancji. Dotyczyć to jednak może spraw mało skomplikowanych, 
do których rozstrzygnięcia nie jest potrzebna pogłębiona, specjalistyczna wiedza prawnicza, lub sytuacji, w których uczestnicy sporu sami decyduja o powierzeniu rozstrzygnięcia swoich spraw zaufanemu zespołowi rozjemców. Takie rozwiązania zwiększają możliwości szybkiego i satysfakcjonującego zakończenia postępowania oraz odciążają sądownictwo powszechne.

Natomiast w poważniejszych sprawach karnych albo skomplikowanych sprawach cywilnych lub administracyjnych niezbędne są wysokie kwalifikacje prawnicze, poparte doświadczeniem życiowym i wymogami etyki. Takie cechy sa niezależne od woli i preferencji wyborców. Tak jak o obsadzie stanowisk lekarskich, inżynierskich czy w większości innych zawodów powinny decydować kwalifikacje merytoryczne i wiedza w danej dziedzinie, tak na stanowiska sędziowskie powinny trafiać osoby mające odpowiednie kwalifikacje prawnicze i moralne. Dlatego władza sądownicza nie powinna być wyłaniana w drodze wyborów powszechnych. Wyborca nie ma bowiem możliwości sprawdzenia i oceny owych kwalifikacji. Moga o tym decydować jedynie ci, którzy mają do tego odpowiednie kompetencje. Takich kompetencji nie ma nie tylko ogół wyborców, ale zapewne także członkowie władz prawodawczych i wykonawczych. Lepiej więc pozostawić te sprawy najbardziej doświadczonym środowiskom prawniczym. Rola innych podmiotów, takich jak np. minister sprawiedliwości lub prezydent, może dlatego sprowadzać się wyłącznie do działań formalnych, tak jak przewiduje to np. art. 179 Konstytucji RP (,Sędziowie sa powoływani przez Prezydenta Rzeczypospolitej, na wniosek Krajowej Rady Sądownictwa, na czas nie oznaczony").

Inne rozwiązania nie tylko stwarzałyby niebezpieczeństwo powoływania sędziów o niewystarczających kompetencjach, ale zagrażałyby zasadzie niezależności sądów i niezawisłości sędziów. Sędzia nie powinien bowiem odczuwać, że jego kariera w jakikolwiek sposób zależy od środowisk polityczno-partyjnych, ani nie powinien być im wdzięczny za to, że został sędzią.

II. Trzy rodzaje władz nieprzypadkowo wyłaniane są w różny sposób. Takie rozwiązanie przyczynia się m.in. do tego, że nie są one podległe jednemu ośrodkowi władzy politycznej. Niebezpieczne sa bowiem dążenia do jedynowładztwa siły politycznej, która legalnie, w wyniku wygrania wolnych wyborów, opanowała najpierw władzę ustawodawcza, a następnie, powołując się na tę wygrana, zamierza sterować pozostałymi, nie wyłączając mediów i organizacji pozarządowych. Niebezpieczeństwo to jest tym większe, im bardziej zostaje zamazane przez pozory zachowania odrębności władz i formalne istnienie wszystkich demokratycznych instytucji. To co w jawnej dyktaturze jest bardzo widoczne i nie budzi wątpliwości, w sytuacji istnienia fikcji ustrojowych pozwala na posługiwanie się różnymi wybiegami formalnoprawnymi. Taka sytuacja wynaturza państwo prawa, prowadzi do faktycznego autorytaryzmu, a w skrajnych przypadkach kończy się dyktaturą. Nie jest to gołosłowne, histeryczne czarnowidztwo. Wystarczy sięgnąc do doświadczeń historii. Dawniej różne formy samodzierżawia, a w XX w. praktyki komunizmu i faszyzmu, w których jednorodność władzy, nawet wyłonionej wolą większości, doprowadzały zawsze do tragicznych skutków. Oczywiście są to przykłady skrajne, dalekie od warunków dzisiejszych. Niemniej warto 
o nich pamiętać, aby uniknąc ryzyka, bezkrytycznie ufając werbalnym zapewnieniom, że tym razem tak się nie stanie, gdyż prawdziwe są deklaracje o nieomylnym programie służącym dobru wspólnemu. Dotychczas bowiem, przynajmniej w naszym kręgu kulturowym, takie zapewnienia nigdy się nie sprawdziły. Może więc lepiej polegać na doświadczeniach zachodnich demokracji, których fundamentem jest rzeczywisty, tzn. niepozorowany trójpodział władz, które wzajemnie się kontrolują i równoważą.

Problem tkwi jednak w tym, że wszystkie władze publiczne, działając w ramach tego samego ustroju państwa, muszą być ze sobą jakoś powiązane. Właśnie te wzajemne związki są najczęściej przedmiotem kontrowersji. W niedawno upadłym systemie tzw. realnego socjalizmu obowiązywała zasada ustrojowa mówiąca o „organach jednolitej władzy państwowej” podporządkowanych jednej sile politycznej. Nie trzeba chyba przypominać, jakie były tego efekty. W demokratycznych państwach prawa władze publiczne powinny wzajemnie się równoważyć, hamując tendencje do osiagnięcia dominacji jednej nad pozostałymi. Dotyczy to w szczególności władzy prawodawczej. Wyłoniona w wyborach powszechnych, słusznie czuje się ona najbliżej „woli ludu”. Nie można się więc dziwić, że zwycięscy politycy starają się ten atut wykorzystywać, przedstawiając własne programy polityczne, jako programy narodu (suwerena). Trójpodział władz ma takie tendencje weryfikować. Nadużyciem jest bowiem twierdzenie, że partykularne interesy zwycięskiej partii zawsze odzwierciedlaja rzeczywiste dobro suwerena, tym bardziej że wyborcy takiej partii reprezentują na ogół tylko część (nie zawsze największa) uprawnionych do głosowania.

Najtrudniej jest osiagnąć względną równowagę pomiędzy władzą prawodawczą i wykonawczą. Władza wykonawcza polega bowiem na bezwzględnym stosowaniu prawa ustanowionego przez władzę ustawodawcza. Ma wprawdzie także ograniczone kompetencje prawodawcze - może np. wydawać rozporządzenia. Jednakże zawsze te kompetencje są ściśle ograniczone ustawą (por. np. art. 92 Konstytucji RP). Problem odrębności władzy wykonawczej sprowadza się głównie do wymogu, aby jej działalność, a zwłaszcza decyzje administracyjne, nie były podejmowane pod naciskiem politycznym (partyjnym), lecz były wyłącznie osadzone w prawie. Ma to gwarantować tzw. służba cywilna niepodlegająca wymianie po każdorazowej zmianie władz politycznych. Dlatego tak ważna jest jej niezależność partyjna.

Nad poprawnością funkcjonowania władzy wykonawczej, m.in. także w odniesieniu do jej apolityczności (apartyjności), czuwa władza sądownicza, a w szczególności sądownictwo administracyjne.

Niemniej jednak utrzymanie czystego, klarownego podziału pomiędzy władzą ustawodawczą i wykonawczą jest mocno utrudnione. Prawodawca może bowiem starać się podporządkować sobie władzę wykonawczą przez wspomniane regulacje prawne oraz decyzje personalne. Najlepszym rozwiązaniem byłaby więc sytuacja, w której wpływ prawodawcy na władzę wykonawcza ograniczałby się wyłącznie do ustanawiania - wiążącego ją - prawa zgodnego z literą i duchem Konstytucji, a egzekutywa zachowałaby niezależność od nacisków polityczno-partyjnych. 
Znacznie wyraźniej rysuje się odrębność władzy sądowniczej. Nieprawdziwe jest twierdzenie, że władza ta znajduje się poza jakąkolwiek kontrola i jest całkowicie niezależna. Bardzo duży wpływ wywiera na nia prawodawca, ustanawiając prawa, które muszą stosować sędziowie. Chodzi jedynie o to, aby prawa te mieściły się w porządku konstytucyjnym państwa. Sędziowie, podobnie jak urzędnicy publiczni, stosują więc prawo, ale powinni przy tym wymierzać sprawiedliwość. Policjant, wypisujac mandat za przekroczenie szybkości, posługuje się ściśle określonym taryfikatorem kar. Natomiast sędzia, stosując normę prawna, powinien uwzględniać cały kontekst sytuacji, która jest przedmiotem rozstrzygnięcia. Bada np. motywy zachowania człowieka, rodzaj winy, okoliczności zdarzeń, ich przyczyny i skutki, uwzględnia problem prewencji itp., itd. Dlatego sędzia powinien mieć szczególnie wysokie kwalifikacje wyrażające się głęboką wiedzą prawniczą oraz wysokim poziomem etycznym. Decyduje bowiem o ważnych sprawach życiowych innych ludzi. Zgodnie $\mathrm{z}$ rotą ślubowania kierować się powinien także własnym sumieniem. Powinno się więc od niego oddalać wszelkie naciski mogacce zakłócać jego obiektywizm ocen. Oczywiście sędzia nie jest nieomylny. Niekiedy popełnia błędy, postępuje nieetycznie, niedbale lub nawet dopuszcza się przestępstw. System wymiaru sprawiedliwości powinien być reformowany tak, aby eliminować podobne przypadki, zracjonalizować zakres kognicji sądów, a sędziom stworzyć odpowiednie warunki pracy tak, aby ograniczyć przewlekłość postępowania. Szkoda, że ostatnie zmiany w sądownictwie nie spełniają tych postulatów, koncentrując się głównie na wymianie sędziów.

W praworządnym państwie jedynym sposobem korygowania błędów sędziowskich jest zasada co najmniej dwuinstancyjności. Tylko sądy wyższej instancji, złożone $\mathrm{z}$ najbardziej doświadczonych sędziów, powołane są do ewentualnego zakwestionowania poprawności wyroków wydanych w niższych instancjach i do ich naprawy. Ta dbałość o gwarancje poprawności orzeczniczej wzmacniana jest niekiedy - tak jak w Polsce - możliwościami kasacyjnymi, skargami konstytucyjnymi, czy nawet odwoływaniem się do sądu ponadnarodowego, jakim jest np. Trybunał Praw Człowieka w Strasburgu. Z tą dbałością nie można jednak przesadzać. Nieustanne wydłużanie stanu niepewności prawnej nie służy dobrze ani obywatelowi, ani państwu.

Ta ważna rola władzy sądowniczej została w państwach demokratycznych uzupełniona o możliwość kontrolowania prawodawcy. Sąy najwyższe w jednych państwach lub trybunały konstytucyjne w innych mają kompetencje sprawdzania konstytucyjności prawa i usuwania norm naruszających konstytucje. Są to więc instytucje uniemożliwiające nadużycia władzy prawodawczej. Ponadto chodzi także o kontrolowanie poprawnego działania podstawowego mechanizmu demokracji, jakim sa wybory powszechne. W tym ostatnim zakresie szczególnie niepokoją próby wprowadzenia do składów orzekających osób delegowanych przez polityków.

Wszystko to pokazuje, jak niebezpieczne mogłoby być pozbawienie władzy sądowniczej przymiotu niezależności i bezpośrednie lub nawet pośrednie jej podporządkowanie sile politycznej dysponującej aktualną większością parlamentarna. Jednak nie tylko to jest istotne. 
III. Trójpodział władz nie jest wyłącznie problemem wynikającym z teorii Monteskiusza. Taka struktura władz publicznych jest także wartościa służącą dobru wspólnemu, a więc pojęciu szerszemu, aniżeli ustrój demokratyczny i państwo prawa. Wniosek ten wynika z przedstawionych wyżej uwag. Teraz wystarczy, w kontekście tych uwag, nawiązać wprost do pojęcia dobra wspólnego.

Konstytucja RP już w pierwszym artykule deklaruje, że „Rzeczpospolita Polska jest dobrem wspólnym wszystkich obywateli”, nie precyzując dokładnie, co ono oznacza. Dobro wspólne można definiować na różne sposoby. Trudno je jednak ująć w ścisłe kategorie doktrynalne, a - tym bardziej - normatywne.

Na ogół dobro wspólne zalicza się do jednej z podstawowych zasad życia społecznego, która powinna służyć całej wspólnocie oraz poszczególnym jej członkom. Jest więc równocześnie wartościa zbiorową i indywidualna, dlatego powinna zapewniać bezpieczeństwo nie tylko państwa, ale także poszczególnych obywateli z ich prawami do obrony przed innymi, w tym przed organami władzy publicznej. Ponadto dobro wspólne polega także na rozwoju gospodarczym i społecznym wyrażanym zarówno w wymiarze całej wspólnoty, jak i pojedynczych ludzi, którzy w tych zakresach mają prawo oczekiwać od władz publicznych poszanowania podstawowych praw i wolności.

Dobro wspólne można więc uznać za istotną rację istnienia władz publicznych, pod warunkiem wszakże, że będą one o to dobro zabiegać. Rzeczywisty, nie tylko formalny, trójpodział władz stwarza w tym względzie pewne zabezpieczenia. Przeciwdziała bowiem dążeniu do jedynowładztwa, grożącego nie tylko niszczeniem ładu konstytucyjnego i zmienianiem go metodami niekonstytucyjnymi (ustawami zwykłymi), ale także bezpośrednio zagrażającego interesom poszczególnych obywateli. Warto więc dbać o to, aby trójpodział władz nie ulegał erozji i był jedną z ważniejszych gwarancji służących dobru wspólnemu.

prof. dr hab. Wojciech Eqczkowski

Emerytowany profesor Uniwersytetu im. Adama Mickiewicza w Poznaniu

oraz Katolickiego Uniwersytetu Lubelskiego Jana Pawła II

\section{TRIPARTITE SEPARATION OF POWERS AND THE COMMON GOOD}

Sum mary

The tripartite separation of powers is an inherent feature of the rule of law characterising democratic systems. The separateness of public authorities is largely determined by the way they are selected. The opposite of the separation of powers is the power of a single person or the omnipotence of a single political power. This situation may arise not only from revolutionary (forced) events, but may also result from legally won democratic elections which the victorious parties invoke, justifying their efforts to permanently monopolise the most important institutions that influence the socio-political and economic activity (including public media and NGOs). Even if they received only a dozen or so percent support from the general public entitled to vote as a result of the electoral law in force, they unjustifiably invoke the 'sovereign will', altering the constitutional principles of the political system by means of ordinary legislation. What is particularly dangerous 
is when the above phenomena are being covered with appearances of the maintenance of the tripartition of powers and a merely formal existence of all democratic institutions that have been, in fact, subordinated to the political will of a single centre of power. Such phenomena are contrary not only to the fundamental democratic principles of the rule of law, but they also threaten the deeper values of the common good which has a collective and individual value. Their violation directly threatens the constitutional system of the state and undermines the legitimate interests of individual citizens. It is therefore worth taking care to ensure that the real (and not simulated) tri-partition of powers is not eroded. 